\title{
KAJIAN WACANA PERCAKAPAN DI FACEBOOK
}

\author{
M. AFIFULLOH \\ UNIVERSITAS BANGKA BELITUNG \\ apiepm@gmail.com
}

\begin{abstract}
There are two types of languages currently used by humans, namely written language and spoken language. These two languages are used separately for different purposes. But in its development, written language and spoken language are used simultaneously so that now the term discussing chatting. This paper attempts to examine the development of these types of languages both from structuralist and functionalist glasses. The two major schools eventually brought this study to the point of problems regarding language, namely discourse. Discourse studies are able to examine languages ranging from words, phrases, clauses, and sentences comprehensively both first order meaning and second order meaning. The result of the study shows that the discourse on Facebook is a different discourse from other forms of discourse. The difference lies in its media, the shape of the text, and the nature of the text. The media is a forum that can be found in cyberspace through computer devices and internet networks. The form of text is in the form of a written conversation between two people or even more. In these conversations between the speaker and the partner do not deal directly but can directly comment, refute, criticize, or approve the opinions of the speaker. The grammatical elements of internet languages are very different which are shown through the structure of the sentence, the presentation of words, and inflection of words. Many choices of words or alphabet that are not everyday language. As an example appears @ (read at), dotcom which is more or less heard by the media
\end{abstract}

\section{Keywords: language, chatting, discourse analysis, facebook.}

\section{PENDAHULUAN}

Melalui bahasa, manusia dapat menjalankan aktivitasnya sebagai makhluk sosial yang tidak dapat hidup sendiri. Manusia butuh interaksi dengan sesamanya dan alat untuk berinteraksi ini disebut dengan bahasa. Ketika manusia melakukan berbagai macam aktivitasnya seperti waktu di jalan, di pasar, di kantor, dan ketika di sekolahan atau lembaga pendidikan lainnya, manusia tidak mungkin terlepas dari penggunaan bahasa. Melalui bahasa ini, manusia mampu berkomunikasi dengan baik tanpa harus beradu fisik atau berbuat kekerasan dan melakukan pemaksaan. Berbicara lewat bahasa akan selalu lebih baik daripada melakukan komunikasi lewat kontak fisik dan kekerasan.

Untuk memahami bahasa secara lebih luas maka munculah istilah wacana. Analisis bahasa secara wacana tidak hanya memandang struktur pembentuk bahasa saja, akan tetapi bahasa dipandang memiliki unsur lainnya yaitu konteks. Konteks dapat berupa konteks linguistik dan juga berupa konteks etnografi. Konteks linguistik adalah struktur pembetuknya (kata, frasa, kalimat, dan seterusnya), konteks etnografi merupakan faktor sosial dan budaya masyarakat pengguna bahasa.

Seiring dengan perkembangan teknologi yang begitu pesat, media bahasa juga ikut berkembang dalam memenuhi kebutuhan manusia untuk berkomunikasi. Komunikasi yang sedang marak dan sangat digemari masyarakat saat ini adalah komunikasi lisan yang tertulis, 
yaitu tidak berwujud ucapan yang dilontarkan dari mulut ke mulut, tetapi berupa teks ujaran atau ujaran yang tertulis. Salah satunya dapat dijumpai dalam dunia maya (virtual word, internet). Forum yang menyediakan percakapan atau dialog antar anggota dengan bahasa tulis melalui media internet dan komputer salah satunya adalah facebook. Percakapan dalam facebook ini merupakan dialog tertulis yang dimanfaatkan oleh pengguna untuk berkomunikasi tanpa harus bertatap muka dan tanpa mengenal jarak dan waktu.

Kehadiran ponsel dan media jejaring sosial seperti facebook harus diakui telah ikut mendorong munculnya ragam bahasa tersendiri. Istilah populernya bahasa alay, bahasa lebay, yakni bahasa tulis berupa campuran bahasa gaul atau bahasa slang kalangan tertentu, bahasa asing khususnya Inggris, singkatan, kode, angka, dan visualisasi. Bahasa ini berkembang di kalangan remaja, namun dalam pergaulan media jejaring sosial juga digunakan orang dewasa yang juga menggunakan media komunikasi tersebut. Bahasa alay pada dasarnya memanfaatkan bahasa prokem anak muda Ibu Kota, ragam bahasa yang berkembang di akhir 1980-an, dan kemudian jadi ragam bahasa media jejaring sosial yang khas. Dalam pergaulan media jejaring sosial, menggunakan bahasa Indonesia yang baik dan benar malah membuat orang tampak aneh, kaku, dan lucu.

Bahasa chatting ini membentuk sebuah komunitas yang memiliki kesepakatan bahasa baru kemudian dijadikan sebagai bahasa sehari-hari dalam berkomunikasi di dunia internet. Bahasa ini menjadi sebuah fenomena sekaligus menjadi kontroversi tersendiri mengingat penggunaannya tidak memiliki aturan yang pasti dan berbeda dari aturan bahasa yang baku.

Banyak istilah-istilah baru yang sering dijumpai dalam percakapan di facebook seperti singkatan-singkatan (OMG, LOL, dan lain-lain), penekanan-penekanan tertentu yang memakai tanda seperti “:), :D, <:," utuk menyatakan perasaan senang, atau penggunaan fonem-fonem tertentu sebagai pernyataan senang atau penghinaan (ejekan) seperti "wkwkwkw", "hahaha", "hehehe", dan lain-lainnya. Hal tersebut muncul sebagai bentuk ekspresi bahasa non-verbal seperti yang muncul dalam percakapan secara langsung. Hal tersebut dirasa sangat menarik untuk dibahas dan diinterpretasi secara luas guna memberikan konsep-konsep yang ilmiah sehingga dapat dikembangkan untuk tujuan ilmu pengetahuan.

Di satu pihak gaya bahasa yang mencapur-adukan bahasa lisan dan bahasa tulis ini dipandang sebagai bahasa yang merusak kebakuan bahasa nasional namun di pihak lain gaya bahasa ini merupakan salah satu bentuk kreativitas anak-anak remaja sekarang pada khususnya yang memang sebagaian besar adalah penggunanya. Lain halnya pendapat yang dikemukakan oleh Kris Bheda Somerpes (2010) ${ }^{1}$. Kris menyatakan bahwa bahasa sejatinya meliputi sistem dan makna. Sistem yang saya maksud adalah lambang-lambang atau kode atau simbol, syarat-syarat pada keadaan-keadaan, tempat-tempat, dan orang-orang tertentu. Sementara makna menunjuk kepada pemahaman dari konsep atau pikiran atau perasaan yang disampaikan. Bahasa Indonesia yang baik dan benar harus efektif, mudah dipahami dan dapat dimengerti oleh lawan bicara. kekayaan simbol, bentuk penulisan yang menggunakan banyak singkatan justru menunjukkan sebuah keunikan dan kekhasan bahasa 'aneh' tersebut. Bagi saya, penggunaan bahasa yang demikian tidak bertentangan dengan bahasa Indonesia yang baik dan benar karena pesan yang mau disampaikan jelas, kendatipun untuk mencernanya agak sulit dan butuh waktu.

\section{KAJIAN TEORI}

\footnotetext{
${ }^{1}$ Kris Bheda Somerpes. (2010). Bahasa aneh: bahasa sms dan bahasa facebook. Diambil pada tanggal 20 April 2015, dari http://edukasi.kompasiana.com/2010/07/28/bahasa\%E2\%80\%98aneh\%E2\%80\%99-bahasa-sms-dan-bahasa$\underline{\text { facebook }}$
} 


\section{A. Pengertian Wacana}

Pengertian wacana yang dikemukakan para ahli bermacam-macam sesuai sudut pandang masing-masing. Menurut Vass, secara etimologi, wacana (discourse) berasal dari bahasa latin "discurrere" (mengalir kesana kemari) dari nominalisasi kata discursus (mengalir secara terpisah yang ditransfer maknanya menjadi terlibat dalam sesuatu, atau 'memberi informasi tentang sesuatu'). Dalam bahasa Latin abad pertengahan kata discursus selain berarti percakapan, perdebatan yang aktif, dan juga keaktifan berbicara, kata ini juga berarti orbit dan lalu lintas. Vass, menjelaskan makna wacana sebagai berikut.

Wacana secara umum merupakan tuturan, percakapan, diskusi. Penyajian diskursif sederet pemikiran dengan menggunakan serangkaian pernyataan. Wacana merupakan serangkaian pernyataan atau ujaran, sederet pernyataan. Bentuk sebuah rangkaian pernyataan/ungkapan;yang dapat berupa arkeologi, wacana ilmiah, puitis, relegius. Perilaku yang diatur kaidah yang menggiring ke arah lahirnya serangkaian atau sistem pernyataan-pernyataan yang saling terkait (=berbagai bentuk pengetahuan) (kedokteran, psikologi, dan sebagainya). Bahasa sebagai sesuatu yang dipraktikan; bahasa tutur. Bahasa sebagai suatu totalitas;seluruh bidang linguistik. Mendiskusikan dan mempertanyakan kriteria validitas dengan tujuan menghasilkan konsensus di antara peserta wacana. $^{2}$

Dari pernyataan tersebut di atas dapat disimpulkan bahwa wacana merupakan sederet pemikiran yang diujarkan lewat bahasa yang memiliki keterkaitan antara deret pernyataan satu dengan deret yang lain yang bisa berupa pemikiran ilmiah, puisi, relegius dan lain-lain.

Van Dijk ${ }^{3}$ menyatakan bahwa "discourse usually refers to a form of language use, public speeches, or more generally to spoken language or way of speakin". Sebagai bentuk dari bahasa dalam penggunaannya, wacana harus di explorasi lewat penelusuran komponen apa yang membentuknya, bagaimana komponen tersebut dibangun, atau mungkin menelusuri bagaimana komponen tersebut berkombinasi sehingga membentuk sebuah konstruk yang luas.

Van Dijk (1997:2), menambahkan bahwa konsep wacana memiliki tiga dimensi yaitu; "language use, the communication of belief (cognition) and interaction in social situation". Jadi, tidak mengherankan jika beberapa disiplin ilmu diperlukan dalam analisis wacana seperti ilmu linguistik (bagi telaah bahasa dan penggunaan bahasa), psikologi (bagi penelitian mengenai keyakinan dan bagaimana wacana dikomunikasikan), dan ilmu sosial (bagi analisis interaksi sosial). J.S Badudu (Eriyanto, 2009:2), menyatakan bahwa:

wacana adalah i. rentetan kalimat yang berkaitan, yang menghubungkan proposisi yang satu dengan proposisi yang lainnya, membentuk satu kesatuan, sehingga terbentuklah makna yang serasi di antara kalimat-kalimat itu; ii. kesatuan bahasa yang telengkap dan tertinggi atau terbesar di atas kalimat atau klausa dengan koherensi dan kohesi yang tinggi yang berkesinambungan, yang mampu mempunyai awal dan akhir yang nyata, disampaikan secara lisan atau tertulis. ${ }^{4}$

2 Titscher, S. et al. (2009), hal. 2. Metode Analisis Teks \& Wacana. Terjemahan oleh Gazali dkk. Yogyakarta: Pustaka Pelajar.

${ }^{3}$ Van Dijk, T. (1997), hal. 1. Discourse as structure and proses. Discourse studies: a multidisciplinary introduction volume 1. London: Sage Publication

${ }^{4}$ Eriyanto. (2009), hal. 2. Analisis wacana. Pengantar Analisis Teks Media. Yogyakarta: Lkis. 
Beberapa definisi di atas tersebut sebenarnya lebih mengacu pada dua aliran besar linguistik yaitu aliran strukturalis dan aliran fungsionalis. Aliran strukturalis lebih mengacu pada struktur bahasa atau teks yaitu anggapan bahwa wacana terdiri dari tingkatan terkecil (kata) sampai tingkatan terbesar (wacana). Wacana ini direalisasikan dalam bentuk karangan yang utuh (novel, buku, seri ensiklopedia, dan sebagainya), paragraf, kalimat atau kata yang membawa amanat yang lengkap.

Sementara aliran fungsionalis lebih mengacu pada fungsi pemakaian bahasa sabagai alat komunikasi. Pandangan fungsionalis ini tidak hanya mengacu pada unsur linguistik yang terdapat di dalam wacana itu akan tetapi lebih luas kepada aspek-aspek diluar yang mendukung terbentuknya wacana tersebut (konteks wacana).

Mulyana ${ }^{5}$ menyatakan bahwa "ciri utama wacana adalah kesatuan maknanya. Sepanjang apapun kalimat dibentuk namun tidak memiliki kesatuan makna, tidak kontekstual, dan tidak dapat dipahami oleh penutur dan mitra tutur maka hal tersebut tidak dapat dikatakan sebagai wacana". Ketika seseorang mengatakan:

"Nasi goreng dua, es jeruk dua, kerupuk satu."

Ucapan tersebut dapat dimaknai sebagai wacana karena memiliki makna yang utuh jika kalimat tersebut dinyatakan saat berada di warung makan. Selain itu, ucapan tersebut memiliki urutan kata yang teratur, kontekstual, dapat dipahami oleh penutur dan mitra tutur.

Dalam percakapan di facebook, wacana yang dimunculkan berupa lontaran ujaran yang dituliskan dengan kalimat sederhana, bertemakan kenyataan sehari-hari, dan memiliki makna dan amanat (mutual Intelligibility), serta kontekstual. Makna yang dimunculkan akan lebih jelas apabila penutur dengan pembaca kenal secara fisik dalam kehidupan nyata. Dalam kenyataannya, penutur dalam percakapn di facebook memiliki kebebasan berucap sesuai tema yang diinginkan.

A: "wah, hari ni so tired....pgn bubuk terus :)"

B: "gek ndang turu, ngebak2i FB ae...wkwkwkw...."

Contoh percakapan di atas tersebut memiliki makna dan pesan yang berkesinambungan antara penutur dan pembaca. Percakapan tersebut juga kontekstual karena dapat dipahami oleh pembaca sehingga bisa ditanggapi. Penulis tidak perlu harus menjelaskan kenapa merasakan capek sementara pembaca tidak perlu bertanya kenapa penulis capek. Pola struktur bahasa percakapan tersebut berbeda dengan percakapan tulis biasa. Hal ini terjadi karena bahasa tulis dalam facebook merupakan bahasa lisan yang dituliskan sehingga penuh dengan ekspresi sebagaimana percakapan secara langsung. Di situ ada tindakan yang diekspresikan melalui gambar atau pemilihan fonem-fonem tertentu sebagai wujud dari tindakan penutur dan mitra tutur.

\section{Teks dan Wacana}

Satuan bahasa dapat dikatakan sebagai sebuah wacana (discourse) atau teks (text) jika satuan bahasa itu membawa amanat yang lengkap. Hal ini sangat bergantung cara pandang satuan bahasa tersebut. Ada pandangan yang menganggap bahwa teks dan wacana tidaklah berbeda, teks dan wacana pada prinsipnya sama.

5 Mulyana.(2005), hal. 5. Kajian wacana: teori, metode, dan aplikasi prinsip-prinsip analisis wacana. Yogyakarta: Tiara Wacana. 
Haliday \& Hasan mengatakan bahwa "kesatuan bahasa yang diucapkan atau ditulis panjang atau pendek, itulah yang dinamakan teks atau wacana". 6 Teks merupakan satu kesatuan semantik dan bukan kesatuan gramatikal, kesatuan yang bukan karena bentuknya melainkan kesatuan artinya.

Sementara Leech \& Short (dalam Mills, 1997: 4) ${ }^{7}$, membedakan antara teks dan wacana sebagai berikut.

Discourse is linguistic communication seen as a transaction between speaker and hearer, as an interpersonal activity whose form is determined by its social purpose. Text is linguistic communication (either spoken or written) seen simply as a massage coded in its auditory and visual medium.

Jadi, wacana merupakan komunikasi bahasa dilihat sebagai sebuah transaksi antara pembicara dengan pendengar, sebagai aktifitas interpersonal dimana bentuk dideterminasi oleh tujuan sosial wacana tersebut. Teks adalah komunikasi bahasa (baik lisan maupun tulis) dilihat sebagai sebuah pesan yang dikodekan melalui media suara atau visualnya.

Adanya pandangan yang menganggap bahwa teks dan wacana itu tidak dibedakan, dan adanya pandangan antara teks dengan wacana itu berbeda disebabkan oleh sudut pandang yang berbeda dalam melihatnya. Ada yang melihat dari unsur linguistik dan nonlinguistik seperti konteks, dan ada pula yang memandang dari aspek-aspek strukturnya. Dengan demikian, dalam kaitannya dengan penelitian yang mengkaji tentang wacana tulis, dapat disimpulan bahwa jika dipandang dari segi proses, memang wacana perlu dibedakan dengan teks. Sebuah wacana percakapan misalnya, jika yang dikaji adalah prosesnya maka wacana merupakan proses komunikasi antara pembicara dengan mitra bicara yang menghasilkan interpretasi. Akan tetapi, jika dipandang dari segi produk maka wacana itu dapat berupa teks sebagai produk bahasa yang menghasilkan makna sehingga wacana tidak dibedakan dengan teks.

Percakapan dalam bahasa chatting seperti di facebook atau twitter merupakan wacana yang berbentuk komunikasi tertulis. Memiliki proses komunikasi dan menghasilkan sebuah teks percakapan. Maka dalam hal ini pendapat yang digunakan adalah pendapat yang tidak membedakan antara wacana dan teks. Wacana dalam percakapan di facebook misalanya, merupakan hasil dari proses komunikasi yang tertulis sehingga menghasilkan teks yang memiliki bentuk dan makna. Wacana ini memperoleh ekspresinya lewat teks dan teks merupakan sarana memunculkan wacana.

\section{Aspek Keutuhan Wacana}

Halliday \& Hasan berpendapat bahwa "structure is, of course, a unifying relation. The part of sentence or a clause obviously 'cohere' which each other, by virtue of the structure". 8 Dalam hal ini keutuhan struktur wacana, lebih dekat maknanya sebagai kesatuan maknawi daripada kesatuan bentuk. Dapat dikatakan bahwa sekelompok kalimat yang menjadi sebuah struktur wacana adalah sekumpulan kalimat yang di dalamnya mengandung hubungan semantik antara bagian yang satu dan yang lain. Tentu saja pernyatan ini mengandung konsekuensi bahwa suatu rangkaian kalimat belum tentu dapat dinyatakan sebagai sebuah wacana karena antar kalimat yang satu dengan yang lain tidak berhubungan secara semantik, artinya masing-masing kalimat berdiri sendiri-sendiri.

${ }^{6}$ Halliday, MAK \& Hasan, R .(1976), hal. 1. Cohesion in english. London: Longman Group Ltd.

${ }^{7}$ Sarah Mills, (1997), hal. 4 . Discourse. London: Routledge

${ }^{8}$ Halliday, MAK \& Hasan, R.(1976), hal. 6. Cohesion in english. London: Longman Group Ltd 
Keutuhan ataupun kelengkapan wacana ditandai oleh adanya unsur kohesi dan koherensi. Kohesi merujuk pada keterpautan bentuk sedangkan koherensi merujuk pada keterpautan makna. Berdasarkan pandangan bahwa wacana yang padu dan runtut adalah wacana yang memilih hubungan antarwujud yang terdapat di dalamnya secara erat, serta hubungan antarmaknanya mengandung keselarasan. Hal-hal yang mendukung adanya kohesi meliputi aspek leksikal, aspek gramatikal, sedangkan yang mendukung adanya koherensi adalah aspek semantik dan aspek yang berkaitan dengan topik wacana.

Agar lebih jelas, berikut ini gambaran lebih mengenai aspek kohesi dan koherensi sebagai faktor pembentuk wacana yang lengkap dan utuh.

a. Unsur Kohesi dalam Wacana

Halliday \& Hasan" menyatakan bahwa "the concept of cohesion is semantic one. It is refers to meaning that exist within text, and that define is as text". Kohesi merupakan hubungan semantis. Merujuk pada hubungan makna yang terdapat di dalam teks, dan definisi makna dalam teks. Kohesi terjadi apabila hubungan beberpa elemen dalam wacana merupakan hubungan yang saling tergantung dengan elemen lain dalam teks. Dalam hal ini, kohesi dapat diartikan sebagai relasi antar bagian dalam wacana yang ditandai unsur-unsur kebahasaan tertentu. Unsur-unsur kebahasaan yang berupa kohesi inialah yang dapat dikatakan sebagai unsur penting dalam pembentukan sebuah wacana, terutama wacana tulis. Kohesi dibedakan menjadi 2 jenis, yaitu kohesi gramatikal (grammatical cohesion) dan kohesi leksikal (lexical cohesion). Kohesi gramatikal antara lain adalah referensi, subtitusi, elipsis, konjungsi, sedangkan yang termasuk kohesi leksikal adalah reiterasi dan kolokasi.

Referensi (penunjukan) merupakan bagian kohesi gramatikal yang berkaitan dengan penggunaan kata atau kelompok kata untuk menunjuk kata atau kelompok kata atau satuan gramatikal lainnya. Dalam konteks wacana, referensi terbagi menjadi dua jenis, yaitu referensi eksoforis (di luar teks) dan referensi endoforis (di dalam teks). Dalam aspek referensi, terlihat juga adanya bentuk-bentuk pronominal (kata ganti orang, kata ganti tempat, dan kata ganti lainnya). Referensi endoforis terbagi menjadi dua, yaitu anafora dan katafora. Unsur wacana yang menunjuk pada unsur lain yang telah disebutkan sebelumnya disebut sebagai anaforis. Sementara katafora merupakan unsur wacana yang menunjuk pada hal-hal yang akan dijelaskan sesudahnya.

Subtistusi (penggantian) adalah proses dan hasil penggantian unsur bahasa oleh unsur lain dalam satuan yang lebih besar. Elipsis (penghilangan/pelesapan) adalah proses penghilangan kata atau satuan-satuan kebahasaan lain. Elipsis juga merupakan penggantian unsur yang kosong (zero), yaitu unsur yang sebenarnya ada tetapi sengaja dihilangkan atau disembunyikan. Tujuannya adalah untuk mendapatkan kepraktisan bahasa. Konjungsi (kata sambung) adalah bentuk satuan kebahasaan yang berfungsi sebagai penyambung, perangkai, atau penghubung antara kata dengan kata, frasa dengan frasa, klausa dengan klausa, kalimat dengan kalimat dan seterusnya. Konjungsi dapat berupa adversatif (namun, tetapi), kausal (sebab, karena), korelatif (apalagi, demikian juga), subordinatif (meskipun, kalau), dan temporal (sebelumnya, sesudahnya, lalu, kemudian).

b. Unsur Koherensi dalam Wacana

Koherensi adalah keterkaitan antara bagian yang satu dengan dengan bagian yang lainnya. Halliday \& Hasan menyatkan bahwa "sumbangan yang penting terhadap koherensi berasal dari kohesi, yaitu perangkat sumber-sumber kebahasaan yang dimiliki setiap bahasa (sebagai bagian dari metafungsi tekstual untuk mengaitkan satu teks bagian teks dengan bagian

\footnotetext{
${ }^{9}$ Ibid. 
lain)". ${ }^{10}$ Teks merupakan kesatuan yang padu, kepaduan suatu teks selain dibentuk oleh kohesi yang menyertainya, ada kepaduan yang dibawa oleh pendengar dan pembaca dari sumbersumber lain, yaitu konteks situasi dan konteks budaya. Dalam keadaan situasi seperti apa teks tersebut dimunculkan dan bagaimana budaya yang melatarbelakangi kemunculan teks tersebut.

Keutuhan yang koheren tersebut dijabarkan oleh adanya hubungan-hubungan makna yang terjadi antar unsur (bagian) secara semantis. Hubungan tersebut kadang terjadi melalui alat bantu kohesi, namun kadang-kadang dapat terjadi tanpa bantuan alat kohesi. Secara keseluruhan hubungan makna yang bersifat koheren menjadi bagian dari organisasi semantis. Unsur koherensi yang terdapat pada suatu kalimat sebenarnya tidak semata-mata terlihat pada satuan teks (secara formal), melainkan juga pada kemampuan pembaca atau pendengar untuk menginterpretasikan suatu bentuk wacana yang diterimanya. Jadi keserasian antara teks dan kemampuan pembaca atau pendengar menerima pesan yang disampaikan merupakan dua unsur pembentuk koherensi. Labov (dalam Mulyana)" , mengatakan bahwa suatu "wacana bersifat koheren, bukan hanya karena hubungan antarbagian, melainkan juga karena adanya reaksi tindak tutur yang signifikan dari pembaca atau pendengar".

Harimurti Kridalaksana ${ }^{12}$ menyatakan bahwa:

koherensi secara struktural, ditandai oleh hubungan pertautan secara semantis antar kalimat (bagian) yang satu dengan kalimat lainnya. Hubungan itu antara lain; hubungan sebab akibat, hubungan sarana-hasil, hubungan alasan-sebab, hubungan sarana-tujuan, hubungan latar-kesimpulan, hubungan kelonggaranhasil, hubungan syarat-hasil, hubungan perbandingan, hubungan parafrasis, hubungan amplikatif, hubungan aditif waktu, hubungan aditif non waktu, hubungan identifikasi, hubungan generik-spesifik, dan hubungan ibarat.

\section{B. Wacana dalam Kenyataan Penggunaan Bahasa}

Wacana sering disamakan dengan bahan bacaan yang terdiri dari beberapa kalimat atau bahkan paragraf. Sebagian ahli menganggap bahwa wacana merupakan satuan bahasa yang paling besar atau tertinggi yang digunakan dalam berkomunikasi. Satuan terbesar artinya bahwa sebelum terbentuk menjadi wacana ada satuan yang lebih kecil sebagai faktor pembentuknya yaitu, kata, frasa, klausa, dan kalimat serta bunyi dalam wacana lisan.

Namun dalam kenyataannya, penggunaan bahasa terutama dalam percakapan baik tulis ataupun lisan, banyak dijumpai hanya terdiri dari satu kata, satu klausa, atau satu kalimat saja dan hal tersebut sering terlihat sebagai kata yang berdiri sendiri namun saling mendukung sehingga memiliki makna yang lengkap dan dapat dikatakan sebagai wacana. Widdowson ${ }^{13}$ mengatakan bahwa "the obvious fact that there are instances of language which have all the appearance of complete texts, but which do not even consist of separate sentences but isolated phares and world". Kenyataannya bahwa ada bahasa yang hanya terdiri dari frasa atau kata saja tetapi memiliki makna yang lengkap tanpa memerlukan satuan kalimat yang panjang.

\footnotetext{
${ }^{10}$ Halliday \& Hasan (1992), hal. 62. Language, context, and text: Aspects of language in a social-semiotic perspective. Terjemahan oleh Asrudin Barori Tou.Yogyakarta. Gajah Mada University Press.

${ }^{11}$ Mulyana.(2005), hal. 31. Kajian wacana: teori, metode, dan aplikasi prinsip-prinsip analisis wacana. Yogyakarta: Tiara Wacana.

${ }^{12}$ Harimurti Kridalaksana. (1984), hal. 29. Kamus linguistik. Jakarta: Gramedia

${ }^{13}$ Widdowson, H.G. (2004), hal 6. Text, context, pretext. Crtical issues in discourse analysis. Malden: Blackwell Publishing.
} 
Ketika tanda $\mathrm{P}$ ada di pinggir jalan maka orang tahu bahwa disitu diperbolehkan memarkir kendaraan. Ketika ada frasa 'sedia bensin' di sebuah toko maka orang tahu bahwa toko tersebut menjual bensin eceran tanpa harus menjelaskan dengan kalimat panjang dan lengkap misalnya seperti 'toko ini menjual bensin eceran'. Tindakan kode dalam konteks, merupakan indikasi simbol percakapan yang disebut wacana.

Wacana dapat dikatakan sebagai proses komunikasi ataupun hasil komunikasi. Dalam komunikasi tulisan, proses komunikasi orang yang menyapa dan orang yang disapa tidak berhadapan langsung. Penyapa menyampaikan gagasan dalam wujud bahasa yang biasa berupa kalimat-kalimat. Rangkaian kalimat tersebut dalam hal ini ditafsirkan maknanya oleh pembaca. Pembaca mencari dan menentukan makna berdasarkan rangkaian kata yang tercetak dalam teks.

Adapun dalam komunikasi lisan seperti percakapan, wacana merupakan proses komunikasi dengan wujud bahasa yang berupa rangkaian ujaran. Ujaran di sini adalah kalimat yang dinyatakan secara lisan. Para peserta tutur dalam komunikasi lisan berbicara secara bergantian dengan bahasa tulis. Percakapan ini terjadi diantara dua orang atau lebih. Penutur mengujarkan gagasan-gagasannya mengenai suatu hal yang dibicarakan kemudian secara bergantian mitra tutur memberikan respon terhadap gagasan yang bisa berupa saran, kritik, penolakan atau sekedar menanggapi penutur.

\section{ANALISIS DAN HASIL PEMBAHASAN}

\section{A. Wacana dalam Dunia Chatting}

Dunia Chatting seperti dalam Facebook adalah ruang dunia maya (virtual world) yang menyediakan fasilitas untuk berkomunikasi dalam bahasa tulis. Percakapan dalam facebook lebih didominasi oleh percakapan yang bersifat non-formal dan bahasa kekini-kinian yang merupakan bahasa sehari-hari kehidupan masyarakat saat ini. Wacana percakapan yang dimunculkan oleh setiap penutur dapat secara langsung ditanggapi oleh mitra penutur dengan menggunakan jaringan internet meskipun jarak antara penutur dengan mitra tutur sangat jauh.

Melalui facebook, setiap orang dapat menjadi anggota dan dapat mengungkapakan apa saja yang ada dipikirannya plus dapat membuat profil tentang dirinya yang dilengkapi dengan foto, data dan catatan lainnya. Kebutuhan manusia modern itu semakin hari semakin membutuhkan ruang dan waktu. Ruang itu adalah media untuk bisa berkomunikasi dan dengan siapapun, sedang waktu, semakin kita membutuhkan segala sesuatu yang dianggap cepat, efesien, dan efektif maka jaringan sosial seperti facebook segera mendapatkan tempat yang terhormat.

Wiliams \& Girish" ${ }^{14}$, menyatakan bahwa "a social network is a set of people, organization, or other social entities connected by a set of socially meaningful relationship". Sekelompok orang atau organisasi ini diberi fasilitas untuk menggambarkan diri mereka, berkumpul secara kelompok, meskipun belum kenal sebelumnya melalui forum komunikasi. Saat ini facebook mampu memosisikan diri sebagai ruang publik yang digunakan sebagai salah satu alat untuk memuaskan hasrat manusia untuk menyalurkan dan mengimplementasikan ide, gagasan, pandangan-pandangan, pengalaman, ideologi, nilai-nilai dan kepentingan-kepentingan melalui media elektronik yang sederhana dan berkualitas. Di dalamnya terdapat percakapan-

${ }^{14}$ William, C. B \& Girrish, J. (2007), hal. 3. Social network in political campaign: facebook and the 2006 midterm election. Chicago: The American Political Science Association. 
percakapan yang santai atau bahkan terdapat berbagai bentuk diskusi yang membahas suatu masalah secara serius dalam kemasan debat publik.

Wacana dalam facebook merupakan wacana yang berbeda dari bentuk wacana-wacana lain. Perbedaan itu terletak pada media, bentuk teks, dan sifat dari teks itu. Media yang digunakan merupakan forum yang tedapat di dunia maya yang penggunaannya lewat perangkat komputer dan jaringan internet. Bentuk teks yang ada dalam facebook ini berupa percakapan tertulis antara dua orang atau bahkan lebih. Dalam percakapan tersebut antara penutur dan mitra tutur tidak berhadapan langsung tetapi bisa langsung berkomentar, menyanggah, mengkritik, atau menyetujui pendapat penutur. Bahasa yang digunakan kebanyakan bersifat non-formal, bersifat santai dan sering dijumpai ketidakteraturan dalam susunan kalimatnya, namun tidak mempengaruhi makna dan maksud penutur.

Sementara gaya bahasa (style) dalam percakapan di facebook berbeda dengan gaya bahasa percakapan pada umumnya. Gaya bahasa dalam percakapan di facebook merupakan gaya bahasa sehari-hari yang dituangkan ke dalam bentuk percakapan tertulis. Penulisannya pun berbeda dengan tulisan rekaman percakapan pada umunya. Perbedaan itu terletak pada banyaknya singkatan-singkatan yang sepertinya sengaja dilakukan untuk mempercepat waktu penulisan tetapi dapat dengan mudah dipahami oleh pembaca.

Gaya bahasa merupakan ciri khas yang pada umumnya terdapat dalam berbagai macam ragam bahasa. Panuti Sudjiman ${ }^{15}$ menyatakan bahwa "sesungguhnya gaya bahasa terdapat dalam segala ragam bahasa: ragam lisan dan tulisan, ragam nonsastra dan ragam sastra, karena gaya bahasa adalah cara menggunakan bahasa dalam konteks tertentu oleh orang tertentu untuk maksud tertentu".

Leech \& Short (dalam Burhan Nurgiyantoro) ${ }^{16}$, menyatakan bahwa "gaya bahasa adalah suatu hal yang pada umumnya tidak lagi mengandung sifat kontroversial, menyaran pada pengertian cara penggunaan bahasa dalam konteks tertentu, oleh pengarang tertentu, untuk tujuan tertentu, dan sebagainya". Dengan demikian, gaya bahasa dapat bermacam-macam sifatnya, tergantung konteks di mana dipergunakan, selera pengarang, namun juga tergantung apa tujuan penuturan itu sendiri.

Dari gambaran tersebut diatas, dapat ditarik suatu benang merah mengenai gaya bahasa yaitu suatu teknik atau cara penulis atau penutur dalam memilih ungkapan kebahasaan sebagai wakil dari apa yang ingin diungkapkan oleh penutur atau penulis sehingga mampu dipahami baik secara langsung atau tidak langsung oleh penerima pesan atau pembaca.

Crystal $^{17}$ (2006:8-9), menyatakan bahwa ada beberapa style yang terdapat dalam bahasa internet yaitu: unsur grafik, orthografi atau grafologi, unsur gramatikal, lexical, dan unsur wacana. Unsur grafik merupakan gambaran dan pengaturan umum dari bahasa tulis. Biasanya ditandai oleh tipografi, desain halaman, spasi, penggunaan ilustrasi-ilustrasi, dan warna-warna tertentu. Ortografi atau grafologi merupakan sistem penulisan yang digunakan oleh individuindividu tertentu. Sistem penulisan ini biasanya ditandai oleh penggunaan alfabet, huruf-huruf kapital, pengucapan, pungtuasi, dan berbagai macam cara pemilihan exspresi (penggunaan font tertentu, seperti italic, bold, dll).

Unsur gramatikal merupakan unsur pembeda bahasa internet yang ditunjukan lewat sruktur kalimatnya, penyajian kata, dan infleksi kata. Misalnya pengguanaan istilah "OMG" (oh

\footnotetext{
${ }^{15}$ Panuti Sujiman. (1993), hal 13. Bunga Rampai Stilistika. Jakarta: Pustaka Utama Grafiti

${ }^{16}$ Burhan Nurgiyantoro. (2009), hal 276. Teori Pengkajian Fiksi. Yogyakarta: Gadjah Mada University Press.

${ }^{17}$ Crystal, D. (2006), hal 8-9. Language and Internet. Engaging \& Provocative Nature (2 ${ }^{\text {nd }}$ edition). New York: Cambridge University Press.
} 
my God) yang berfungsi untuk memperlihatkan kereligiusan penulis dalam menghadapi atau mendapat suatu pengalaman tertentu. Unsur leksikal merupakan unsur-unsur yang menunjukan kepada pengguanaan kosakata bahasa atau sekumpulan kata seperti idiom dan lain-lain. Kemudian unsur wacana dapat berupa perbedaan bahasa internet dengan bahasa lainnya yg ditunjukan dengan perbedaan pengorganisasian teks seperti koherensi, relevansi, struktur paragraf, dan keruntutannya.

Gaya bahasa yang terdapat dalam percakapan di facebook memiliki unsur-unsur yang sangat dipengaruhi oleh media yang digunakan. Banyak pemilihan kata atau alfabet yang bukan merupakan bahasa sehari-hari. Sebagai contoh muncul @ (di baca at), dotcom yang merupakan sedikit banyak dipengarurhi oleh media. Unsur@pada kalimat “@ coffeshop, lagi nongkrong ma temen-temen" menunjukan dia sedang berada di tempat tertentu yaitu di coffeshop. Munculnya istilah @ pada awalnya digunakan untuk mengrimkan e-mail kepada alamat tertentu. Istilah ini pertama kali digunakan oleh sarjana computer Ray Tomlinson yang memilih inisial @ agar tidak sama karakternya dengan nama tertentu.

\section{B. Bahasa Lisan dan Bahasa Tulis}

Bahasa telah mengalami perkembangan yang sangat signifikan dalam penggunaannya. Menurut Little ${ }^{18}$, pada awalnya, bahasa digunakan untuk berkomunikasi secara lisan (oral) oleh manusia untuk menyampaikan sesuatu kepada manusia lain, kemudian dalam perkembangannya, bahasa tidak hanya diujarkan secara lisan saja tetapi secara tertulis (written) yang berupa teks sehingga muncul istilah komunikasi tertulis dan komunikasi lisan (written and oral communication).

Bahasa lisan dalam perkembangannya lebih cepat dibandingkan dengan bahasa tulis. Manusia selalu mencari cara dan berfikir untuk menjelaskan apa yang ingin dijelaskan kepada sesama manusia tentang ide, perasaan, dan lain-lain. Menggunakan bahasa baru sesuai dengan perkembangan jaman atau menggunakan kata-kata lama untuk menambah efek tertentu biasa dilakukan manusia dalam berkomunikasi.

Pada tataran pemilihan kata, bahasa lisan lebih bervariasi dari pada bahasa tulis. Banyak bahasa lisan yang berkembang dan sering digunakan dalam percakapan sehari-hari oleh masyarakat tetapi tidak dapat diterima oleh bahasa tulis terutama bahasa tulis formal. Little mengatakan bahwa "words and exspressions which are current in speech but not fully accepted into written language are called 'colloquialisms'" 19 . Bahasa yang tidak sepenuhnya dapat diterima oleh bahasa tulis adalah bahasa kolokial.

Pada tataran gramatikal suatu bahasa, bahasa lisan banyak dijumpai memiliki struktur yang tidak lengkap dan terkesan salah, sementara bahasa tulis harus lengkap dan sesuai dengan aturan yang berlaku.

P:"Sudahkah kamu makan siang hari ini?"

Y: "Udah maem siang lum hari ni?"

Pada ungkapan yang diucapakan $\mathrm{P}$, kalimat Tanya tersebut memiliki susunan kata yang sesuai dengan kaidah bahasa Indonesia yang berlaku dan lengkap. Sementara pada ungkapan Y

\footnotetext{
${ }^{18}$ Little, P. (1973), hal. 13-14. Oral and Written Communication. New York: Longman Group Limited.

${ }^{19}$ Ibid.
} 
tidak sesuai dengan kaidah bahasa yang berlaku dan tidak lengkap. Pemilihan kata pada Y bersifat kolokial, artinya ungkapan tersebut tidak dapat sepenuhnya diterima oleh bahasa tulis.

Perbedaan yang lain antara bahasa lisan dan bahasa tulis adalah faktor non-verbal dalam komunikasi. Gerak tubuh waktu berbicara, isyarat mata, intonasi, mimik wajah, dan lain-lain ikut berkomunikasi dalam bahasa lisan seperti yang diungkapkan oleh Little ${ }^{20}$, bahwa "when we speak, other media operate in parallel to the main medium of words. These media include such factors as volume and tone of voice, facial expressions, and gesture". Sementara Van Dijk ${ }^{21}$ menyatakan bahwa "text is mostly used to refer to the product of writing, talk is often studied as the product of speaking or as ongoing interaction, without paying much attention to the language users involved or other aspects of the whole communicative event". Teks digunakan untuk memroduksi tulisan, sementara bahasa lisan merupakan produk dari percakapan atau interaksi yang terjadi secara langsung tanpa memperhatikan bahasa yang digunakan pengguna atau aspek lain dalam peristiwa komunikasi.

Perkembangan teknologi yang sangat pesat dewasa ini berdampak pula pada perkembangan bahasa. Bahasa yang dulu hanya memiliki dua jenis yaitu bahasa lisan dan bahasa tulis kini muncul bahasa lisan tertulis. Bahasa lisan tertulis ini banyak dijumpai pada chat online (forum komunikasi dalam internet). Bahasa yang digunakan berupa bahasa lisan, diujarkan lewat bahasa tulis, memiliki fungsi untuk berbagi berbagai hal seperti pengetahuan, pengalaman, ide atau gagasan, dan lain-lain seperti pendapat Ling Tan \& Chee Tan ${ }^{22}$ yang menyatakan bahwa "both face-to-face and online encounters have elements of cultural and social dimensions of knowledge; these knowledge manifest as shared meanings, judgments, and understandings of expressed thoughts and beliefs within a specific context". Percakapan sacara langsung maupun secara online sama-sama memiliki elemen-elemen budaya dan dimensi sosial pengetahuan. Pengetahuan tersebut dimanifestasikan dengan berbagi makna, penilaian, dan pengertian yang diekspresikan melalui kepercayaan dan keyakinan dalam konteks yang khusus.

\section{KESIMPULAN}

Perpaduan antara bahasa lisan dan bahasa tulis menyebabkan adanya percampuran karakteristik antara bahasa tulis dan bahasa lisan. Bahasa percakapan di facebook memiliki unsur verbal dan non-verbal bahasa, memiliki pola yang tidak teratur seperti pola bahasa lisan, bersifat kolokial, tetapi bersifat tertulis (dalam bentuk teks).

Sebagai media komunikasi, bahasa chatting dapat dikategorikan bahasa yang telah memenuhi semua unsur wacana meskipun unsur-unsur yang dimaksud kadang berbeda dari bahasa tulis lainnya. Selama proses penyampaian ungkapan dapat dimengerti lawan bicara, maka

\footnotetext{
${ }^{20}$ Little, P. (1973), hal. 19. Oral and Written Communication. New York: Longman Group Limited

${ }^{21}$ Van Dijk, T. (1997), hal.3. Discourse as structure and proses. Discourse studies: a multidisciplinary introduction volume 1. London: Sage Publication.

22 Ling Tan, A. \& Chee Tan, A. (2011), hal. 250. Conversation analysis as a tool to understand online social encounters dalam Daniel, Ben Kei. (2011). Handbook of research of Methods and techniques for studying virtual communities. Paradigms and phenomena. Volume I. New York. IGI Global.
} 
bahasa chatting sah-sah saja menjadi bahasa pergaulan sehari-hari namun bukan untuk bahasa ilmiah.

\section{DAFTAR PUSTAKA}

Burhan Nurgiyantoro. (2009). Teori pengkajian fiksi. Yogyakarta: Gadjah Mada University Press.

Brown, G. \& Yule, G. (1983). Discourse analysis. New York: Cambridge University Press.

Crystal, D. (2006). Language and internet. Engaging \& provocative nature (2 $2^{\text {nd }}$ edition). New York: Cambridge University Press.

Eriyanto. (2009). Analisis wacana. Pengantar analisis teks media. Yogyakarta: Lkis.

Halliday, MAK \& Hasan, R .(1976). Cohesion in english. London: Longman Group Ltd.

(1992). Language, context, and text: Aspects of language in a social-semiotic perspective. Terjemahan oleh Asrudin Barori Tou.Yogyakarta. Gajah Mada University Press.

Harimurti Kridalaksana. (1984). Kamus linguistik. Jakarta: Gramedia

Kris Bheda Somerpes. (2010). Bahasa aneh: bahasa sms dan bahasa facebook. Diambil pada tanggal $20 \quad$ April 2011, dari http://edukasi.kompasiana.com/2010/07/28/bahasa\%E2\%80\%98aneh\%E2\%80\%99bahasa-sms-dan-bahasa-facebook.

Ling Tan, A. \& Chee Tan, A. (2011). Conversation analysis as a tool to understand online social encounters dalam Daniel, Ben Kei. (2011). Handbook of research of Methods and techniques for studying virtual communities. Paradigms and phenomena. Volume I. New York. IGI Global.

Little, P. (1973). Oral and written communication. New York: Longman Group Limited.

Mills, S. (1997). Discourse. London: Routledge. 
Mulyana.(2005). Kajian wacana: teori, metode, dan aplikasi prinsip-prinsip analisis wacana. Yogyakarta: Tiara Wacana.

Panuti Sujiman. (1993). Bunga rampai stilistika. Jakarta: Pustaka Utama Grafiti.

Titscher, S. et al. (2009). Metode analisis teks \& wacana. Terjemahan oleh Gazali dkk. Yogyakarta: Pustaka Pelajar.

Yoce Aliah Darma. (2009). Analisis wacana kritis. Bandung: CV. Yrama Widya.

Yule, G. (2006). Pragmatik. Terjemahan oleh Indah Fajar Wahyuni. Yogyakarta: Pustaka Pelajar.

Van Dijk, T. (1997). Discourse as structure and proses. Discourse studies: a multidisciplinary introduction volume 1. London: Sage Publication.

Widdowson, H.G. (2004). Text, context, pretext. Crtical issues in discourse analysis. Malden: Blackwell Publishing.

William, C. B \& Girrish, J. (2007). Social network in political campaign: facebook and the 2006 midterm election. Chicago: The American Political Science Association. 